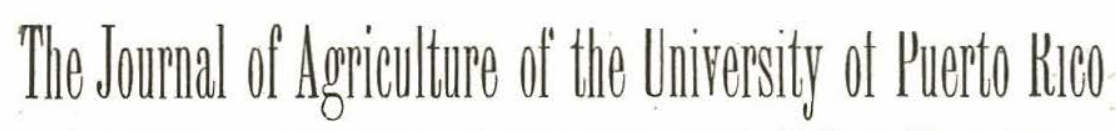

In continuation of The Journal of the Department of Agriculture of Puerto Rico

Publiahed Quarterly: January, April, July and 0ctober of each year.

Melville T. CoOK, EDitor

VoL. XX

JULY 1936

No. 3

\title{
RECORDS OF VIRUS DISEASES OF PLANTS IN PUERTO RICO
}

\author{
Melviwle T. Cook, Plant Pathologist, \\ Agricultural Experiment Station, Río Piedras, P. R.
}

These records are published at this time for the use of those workers who may be interested in the subject. Although the data is not complete it is made available for those who may want to use it.

\section{AMARILIDACEAE}

Eucharis grandiflora Planch (E. Amazonica Linstl.) This species is attacked by a mosaic which was reported by the writer in 1931 . Up to the present time the writer has not found an individual of this species that did not show the disease. This disease is mentioned in the literature but the writer has not been able to find the first record. Bremer reported a stripe disease in 1926 which may be the same.

\section{BIXACEAE}

Maximiliana vitifolia (Willd) Krug \& Urban. This is an introduced plant which has developed very pronounced mosaic patterns ranging through shades of green and yellow. It has been transmitted by budding. First published record.

BROMELIACEAE

Ananas ananas (L) Cockerell. The yellow spot and wilt diseases have been introduced from Hawaii on two shipments of slips of the smooth Cayenne variety, one in 1923 and the other in 1931. Both shipments were kept under observation for about two years and appeared to be perfectly healthy. In 1934 the yellow spot and wilt diseases (which are well known in Hawaii) were found in both plantings and they were placed under quarantine. These diseases corresponded to the descriptions of the diseases in Hawaii and have been controlled by controlling the ants. 
A very similar symptom has appeared on the Cabezona pineapples in the vicinity of Lajas. This diseased condition has been known for several years and this variety has been degenerating, but the writer and others who have visited that region have failed to determine the cause of the trouble. Recent studies by the writer indicate that the discase is similar to yellow spot and wilt diseases of Hawaii but that the symptoms are not exactly the same. The writer plans to continue his studies on this disease.

The writer also found the spike disease in the Cabezonas recently. This disease was reported from Puerto Rico a number of years ago but has not been found during the past thirteen years that the writer has been on the Island.

\section{COMPOSITAE}

Bidens cynapiifolia H. B. K. This plant is subject to severe attacks of mosaic. In its mild form the disease produces a pattern which may be described as more or less blotchy in character. In the severe forms the leaves are more or less deformed.

\section{CUCURBITACEAE}

Cucumis sativus $\mathrm{L}$. The mosaic disease was very severe during growing (winter) season of 1935-36. Many fields in the eastern part of the Island showed an infection of 100 percent. This is the first severe outbreak of this disease that has come to the attention of the writer during past thirteen years of residence on the Island. During that time the writer was never able to find more than one or two diseased plants in any planting.

\section{DIOSCORIACEAE}

Dioscorea sp. (cultivated variety). Some plants have been found showing well defined mosaic patterns and others that were uniformly chlorotic. The exact nature of this disease has not been determined.

\section{EUPHORBIACEAE}

Adenoropium gossypifolium L. A mosaic disease was reported by the writer in 1931. Recent studies indicate that it is not transmitted by the seeds but it is very easily transmitted by budding.

\section{GRAMINEAE}

Zea mays L. The writer has found a stripe disease of corn which appears to be the same as the stripe diseases reported by 
Britton Jones (1923) in Trinidad and by Stahl (1927) in Cuba. This disease is characterized by cholorotic stripes following the veins of the leaves. These stripes are very narrow. The stripe symptoms appear on the upper 4 or 5 or 6 leaves only. In the first generation, some of the plants will be barren. In the second generation many seeds will not germinate, many plants will be dwarfed and barren, the larger plants will show the stripe symptoms and some of them will be barren. In the third generation these symptoms will be intensified and very few plants will produce grain. The disease is transmitted in the seeds.

\section{LEGUMINOSEAE}

Bradburya virginiana L. Kuntz. This species is subject to a well defined mosaic which is probably the same as the common bean mosaic. The experiments made by the writer indicate that it is not transmitted by seeds but Aphis rumicis is the probable vector.

Crotalaria anagyroides $\mathrm{H}$. B. K. This species is subject to a mosaic which appears to be the same as the one on C. striata which was reported by the writer in 1931. Tests indicate that it is not transmitted in the seeds.

Crotalaria usaramoensis E. Baker. This species is subject to a mosaic which appears to be the same as the one on $C$. striata which was reported by the writer in 1931. Tests indicate that it is not transmitted by in the seeds.

Phaseolus lunatus L. This species is attacked by a virus which is probably the same as the common bean mosaic. Tests thus far indicate that it is not transmitted by the seeds. The writer suspects that Aphis rumicis may be the vector but we do not have any experimental proof.

\section{MALVACEAE}

Althae rosea (L.) Cav. This species is affected with a mosaic which was reported by the writer in 1935 . Tests up to the present time indicate that the disease is not transmitted by the seeds but by an unknown insect vector.

\section{MUSACEAE}

Musa sp. The writers attention has been called to a mosaic disease of banana. This disease has been reported from other parts of the world. It is very rare in Puerto Rico.

Musa sp. A virus disease or virus-like disease is very abundant on the "enano" plantain in Puerto Rico. This disease appears to be very different from the bunchy top disease of the Far East and 
684 THE JOURNAL OF AGRICULTURE OF THE UNIVERSITY OF P. R.

does not correspond to the descriptions of diseases recently reported from Florida and Trinidad. Thus far it has been found on but one variety.

The spirals of diseased plants do not unroll properly. Sometimes. they are bent to form hooks. Parts of the outer leaf may become dead, brown and torn by the growth of the inner parts. When the leaves of the spiral are first unrolled, they are chlorotic and crinkled and in severe cases become brown and die.

\section{PASSIFLORACEAE}

Passiflora laurifolia L. This is a very severe but rare chlorotic disease. The leaves are underveloped in size and irregular in shape. The writer has not demonstrated that this disease is due to virus.

\section{STERCULIACEAE}

Helicteres jamaicensis Jacq. A very pronounced case of a mosaic on this species was brought to the writer June, 1936, by Mr. W. A. McCubbin. Although we have no experimental proof that this is a virus disease the symptoms are so characteristic that it should be included in these records. 